\title{
The Heritage of Cultural Determinants of Law and Literature: Methodological Findings
}

\author{
Marta Andruszkiewicz ${ }^{1}$ (D)
}

Published online: 1 July 2020

(c) The Author(s) 2020

\begin{abstract}
During the second half of the twentieth century, the humanities saw increased interest in the broadly defined theory of culture and theory of politics, and in their study in a pragmatic cultural context. This was due to the influence of postmodernism, as well as pragmatism and neo-pragmatism. This approach is developed in cultural studies, which stress the importance of interdisciplinary research, combining the semiotic and cultural perspectives. The humanities have experienced a series of watersheds or turns (such as the linguistic, interpretative, political and communicative turns), and in particular the cultural turn. In consequence, the boundaries of various scientific disciplines are becoming blurred, while the scope of theoretical literary research is expanding. The integration of humanistic disciplines has intensified. This has an effect not only on the philosophical and theoretical study of language and literature, but also on the theory of politics and theory of law. As a result of these changes, various cultural objects-politics, the law, literature-have become the subject of complementary research. Cultural research assumes the cultural intertextuality of different semiotic objects, especially of text and discourse. This paper describes the influence of cultural studies — as a legacy of cultural determinants — on the law and literature movement. It also answers the question of what that movement can derive from cultural studies. The paper provides an overview of key trends, which may receive more detailed treatment in future studies.
\end{abstract}

Keywords Cultural studies $\cdot$ Law and literature $\cdot$ Poststructuralism $\cdot$ Legal and literary interpretation

Marta Andruszkiewicz

andruszkiewicz@uwb.edu.pl

1 Chair of Theory and Philosophy of Law, Department of Law, University of Białystok, Białystok, Poland 


\section{Introduction}

The concepts of literary analysis of the law, referred to as law and literature, may serve as a platform for study of the grounding of cultural heritage and its variation in time and space. This is a diverse, complex field, forming part of Critical Legal Studies. It is sometimes associated with American postmodernist jurisprudence, in view of the subject studied or the methods adopted. Some researchers also point to a relation with Jacques Derrida's deconstructionist point of view, and H.G. Gadamer's hermeneutics. According to Jeanne Gaakeer, a contemporary Danish researcher in the field, literary analysis of the law refers to the concept of the law as a human activity that has the property of creating meaning [8]. This approach refers to the interdisciplinary areas of research focused on the study of text and interpretation. The currents referred to as cultural studies, present especially in literary theory, are particularly inspiring. The contemporary theory of law takes note of the cultural foundations of language, and of the fact that human interpretative activity is rooted in culture. The point of support for the reality of law is the socially generated reality of culture. The law functions through an institutional structure shaped by society, with its own professional semantics. This structure enables it to assign specific cultural meanings to other elements of the social world [10, p. 104ff].

\section{The Law and Literature Movement}

The starting point for the studies referred to as literary analysis of law is the assumption that there are important relations between law and literature. This current covers various issues arising from the integration of jurisprudence with the theory of language and literary theory. Interest in ties between law and literature grew in the 1970s, when interdisciplinary legal research developed. It acknowledged the viewpoint of other disciplines: sociology, psychology, economics, the science of communication, language and literature. However, interest in these matters first arose much earlier. John H. Wigmore published his famous list of legal novels in 1908, consisting of outstanding works of world literature that include depictions of the law, legal systems, lawyers, and legal practice. Wigmore regarded this as a list of books with which every lawyer should be familiar. James B. White is credited as the founder of the law and literature movement. His famous work, The Legal Imagination (1973), summarized the founding principles of this area of research. The perspective he proposed was an attempt to apply methods used in literary theory to the study of legal texts. Also noteworthy is Benjamin Cardoso's 1931 essay Law and Literature. It analyzes the language activity of lawyers from the perspective of literary features, taking as an example the reasoning for judgments written by judges.

The law and literature movement was originally expected to overcome the stereotypically hermetic nature of legal language and legal circles, and to bridge the 
communication gaps between the legal and non-legal worlds [3, p. 335]. Literary analyses were considered the source of models for correct communication. This was tied to the question: what can a lawyer learn from literature, or what do lawyers need literature for [3, p. 335]? Wigmore claimed that there are many literary works that every lawyer should read due to cultural and professional considerations. According to Jeanne Gaakeer, the goal was 'to look upon law as a language that proposes a certain form for the world, and as a cultural competence in the sense of the activities that lawyers perform' [8]. This approach to the law and literature movement contains a cultural accent. The law is seen as a linguistic message offering a certain vision of the world which develops the cultural competence required and fulfilled by lawyers.

Within the subjects linking law and literature, studied by theorists in both fields, two main perspectives are traditionally distinguished: law in literature and law as literature. The first analyzes motifs and topoi associated with the law. It is referred to as the external perspective. Law in literature focuses on the representations and visions of the law in its broad sense-allegorical, fictional, historical, etc.-that appear in literary works. Scholars analyze works by Sophocles, William Shakespeare, Miguel de Cervantes, Fyodor Dostoyevsky, Franz Kafka, Albert Camus, Herman Melville, Milan Kundera and many other authors. Such points of reference support learning about various aspects of the functioning of the law, and promote knowledge about the specificity of legal cultures and the characteristics of the law in its diachronic development. These studies are similar to literary criticism. The internal perspective (law as literature) centers on the theoretical and literary analysis of the structural, semantic and stylistic properties of legal texts, examined by means of the techniques used by literary scholars. Legislative activity may be perceived as a type of linguistic creativity, like the creation of other types of texts, including literary ones. Matters of legal and literary interpretation are of particular interest under this perspective. There are many similarities in the specifics of interpretative practice in these two areas, as has previously been noted in the subject literature. [See e.g. 1, pp. 183-197].

The law and other fields involved in cultural communication coexist in the cultural and communicative context. This is an argument for the need to conduct indepth research treating law and literature as convergent areas. It should be noted that although such research is long established in many Anglo-Saxon and European countries, in Polish jurisprudence it is still in its early phase. It would appear that from the standpoint of the trends described here, this traditional division into two directions of research may be complemented, or at least extended, by the cultural perspective of research into the relations between law and literature. The influential research trends described below show how appreciation of the cultural determinants of law and literature may be inspiring to the contemporary lawyer. 


\section{Poststructuralism-Pragmatism: Cultural Studies}

In the current state of studies of law and literature, one of the most inspiring areas is cultural studies, influenced by poststructuralism and neo-pragmatism. ${ }^{1}$ It is based on the assumption of the cultural intertextuality of both law and literature. Law and literature share a common cultural and communicative context. The law is both a product and component of culture, as are literature and other areas of human activity. This concept is based on the neo-Kantian assumption that the law is an object of culture. As such, the law uses specific resources of codes and symbols. It is a means for the lawmaker to communicate with subjects of the law, an instrument for regulating behavior, a medium of values, and a tool for determining value in culture. Viewing the law from the standpoint of literary analysis, one can examine it on the basis of affiliation with the same cultural circle and the same values. The language of legal texts is a reflection of the specific features of the cultural context to which it belongs, because language is the most fundamental fact of culture. A legal text is a semiotic object, which is a tool for conveying information, communicating and valuing. The law-making process and its social reception, in its broad sense, are entrenched in the culture and axiology of a given society. The law itself is a complex semiotic object in the sphere of social symbols. The law, like other products of human activity, and literature, realizes the rituals, habits, and thinking paradigms that are rooted in human development - the beliefs, symbols and codes common to a given culture. Thus, legal texts can be seen as a way of communicating information on the cultural, social and axiological determinants of society at a given stage of its historical evolution. As is pointed out by the author cited above, the literary point of reference for studies of law and literature is a set of works of literature-not only those which make up the canon of world literature, but also those which can be regarded as 'the literary works explicitly challenging that canon, as it is taken to be the study of language and the study of culture in a broad sense' [8].

Poststructuralist tendencies inspired the integration of the study of law and literature in the twentieth century. Literary theoreticians researching in the area of cultural studies use the term poststructuralism 'for a broad range of theoretical discourses in which there is a critique of notions of objective knowledge and of a subject able to know him or herself' [4, p. 125]. It has influenced those areas of knowledge whose subject of interest is text. The central problem analyzed by poststructuralism is the communicative and discursive nature of human activity in the public sphere, where varied pluralist discourses coexist. Under this approach, similar research methods can be applied to the analysis of different types of texts-literary, political, legal, etc.- because they are products of culture. This approach is specific to the philosophies of pragmatism and neo-pragmatism — as conceived, for instance, by Richard Rorty or Stanley Fish. The primary plane of cultural studies and the goal of literary

\footnotetext{
1 This was significantly influenced by several currents and tendencies in the contemporary humanities, including in the semiotic approach to the law-aside from cultural studies and poststructuralism-the post-analytic perspective of philosophy of law, critical studies of the law, and the reactivation of hermeneutic methods in interpretation.
} 
criticism is social activism - the cultural, social entanglement of literature in the political. As Richard Rorty stated, nowadays a poet can accomplish more than a politician. A skeptical approach is represented by another theoretician of pragmatism, Richard A. Posner. In his opinion, contemporary literary theory has indeed changed its attitude: from literature as traditionally understood to writings in their broadest sense, which may include legal texts. However, this has not brought law and literature closer together. It has nonetheless led to the development of cultural studies, 'the aim of which is to knock literature off its pedestal and find vehicles easier than literary works for making political points' [13, p. 8]. The author appears to overlook the benefits that a researcher in law can obtain from the integration of literary theory and legal theory in a cultural context. This concerns, among other things, changes in the view taken of text and language as objects of interdisciplinary study.

\section{Cultural Analysis of Text and Language}

The well-known law and literature scholar Kieran Dolin claims that although law and literature are separate areas, their boundaries overlap because of their common interest in language [6, pp. 8-9]. The cultural perspective of the law and literature movement presents the law as an object of culture and an artistic artifact. The applicability of literary research tools to the analysis of legal and law-related texts has been addressed by Gary Minda. He points out that law and literature are closely linked, in that both fields are based on language and on specific ways of writing, reading and speaking. Minda stresses that law can be considered as a unique literary genre, whose study requires new methods of critical analysis taken from the current of law and literature [12, p. 245]. For researchers in law, it may be helpful to consult not only works from the canon of world literature (as has been done so far), but also critical texts from the areas of literary theory, poststructuralism and deconstruction. These texts make it possible to explain the specific features of legal texts by means of literary categories, specifically through their shared cultural context.

The meaningful concepts of the contemporary humanities, referring to poststructuralist trends and to cultural studies, extend the scope of literary theory. They assume an interdisciplinary approach to text. They stress that both literary and nonliterary texts can be analyzed in a similar manner, making use of the accomplishments of the relevant fields of learning [4, p. 18]. They argue that the tools of literary studies - applied thus far to the study of literary texts - can be useful for the analysis of all kinds of texts functioning in culture and in social communication, understood broadly as cultural texts or semiotic objects. The converse also holds. Non-literary texts can be analyzed through reference to the tools of literary theory. Particularly in the perspective of cultural research, the possibility of applying the tools of literary studies to analyze a genre of expression need not require that genre to be classed as literature [5, pp. 5, 15]. Under this approach, the different aspects of legal practice can be viewed as the creation of texts of various kinds, or as examples of the art of speaking and writing [15, p. xiv]. In the different areas of law-legislation, adjudication, interpretation-language is the material and the tool for constructing texts. Legal texts are drafted in accordance with the requirements for legislation 
functioning in the legal culture, and interpreted with the use of established rules of legal exegesis. A legal text is an esthetic artifact sui generis, the outcome of applying conventionally accepted rules. Texts-court judgments, administrative decisions, explanatory statements - are also created in adjudication and in legal practice. The cultural approach to language and text presents them as a network of discourses conditioned by situation. The cultural point of view shows that different varieties of 'literariness' appear in different types of discourse [4, p. 18ff]. This means that typical literary construction techniques can be discerned in law. Specific textual, stylistic or rhetorical patters are found in this specific type of language creation. They may include such representative examples of literariness as narrativity, performativity, fictionality, metaphoric quality, petrified language phrases and formulas, etc. [2, pp. 73-79]. Thus, cultural studies persuade us that the tools of literary research can be applied to the analysis of legal and law-related texts. This is evidenced by the fact that in law, just as in literature, use is made of conventional fiction, the creation of a linguistic picture of the world, fixed schemes of text structure, and intertextual techniques. In cultural studies, a further shared feature of law and literature is the issue of interpretation.

\section{Cultural Determinants of Interpretation}

Poststructuralism and cultural studies have influenced the concepts of the meaning of a legal text, legal interpretation, and even the concept of the law itself. This offers a space for the application of literary analysis of the law, in particular for the pragmatic concept of interpretation. Under this concept, interpretation is considered the creative practice of determining the meaning of a text. American pragmatism drew attention to how philosophy and literary theory are linked to politics in the cultural public sphere. The pragmatic interpretation theory is based on the phenomenological thesis that human existence and intellectual presence in the world constitute a creative activity. This action is manifested also in practices of interpretation, as is reflected in the theory of reader-response criticism. ${ }^{2}$ The interpretative turn-linked to pragmatism-prompted the reactivation of methods of legal hermeneutics as means of interpretation. Under this creative approach to interpretation, the law is an occasional phenomenon, an obligation. Its content is created in the situation of adjudicating in the light of the contextual nature of the case in question. This brings legal interpretation close to literary interpretation. As Jeanne Gaakeer writes, 'that both legal and literary interpretation demands our active participation which subsequently should promote awareness of our own role in the act of creation of meaning' [8]. Law and literature are interlinked in a specific manner. Both fields are based on language and on specific manners of writing, reading and speaking, which include related interpretation practices [11, p. 150]. The legal text contains a 'reflection'

\footnotetext{
2 The theory of reader-response criticism was formed in the 1960s and 1980s. Stanley Fish is considered to be the founder of this movement. This same point of view has been represented by other researchers, including Norman Holland and David Bleich.
} 
of the image of culture. This view is both cultural and poststructuralist. This poststructuralist 'entanglement' with culture occurs through language. The meaning of a legal text is determined through arguments, within a specific cultural discourse. 'Legal interpretative procedure is at most a special case of legal argumentation' [17, p. 476]. Legal discourse is a special case of practical discourse. In interpreting a legal text, a contemporary lawyer takes into account contextual factors that determine the method of interpretation adopted for a given in a particular case. In Polish philosophy of law, the cultural context is noted by such scholars as Marek ZirkSadowski, who claims that the perception of the law as an object of meaning that is not a 'ready' subject offered to the person analyzing it is justified by the fact that the law is also a way of participating in culture. Zirk-Sadowski notes that integration processes influence the perception of law as a product of the act of communication. In consequence, a concept is formed of the law as a cultural object: 'a system of some meanings' [16, pp. 6, 128]. A lawyer explaining a legal text-a complex semiotic object-decodes the normative meanings (fragmented and condensed in regulations). He applies methods and tools developed in legal doctrine and jurisprudence, in legal culture, but also in the social, cultural and axiological context.

In Polish legal theory too there is a change of approach to adjudication and to the interpretation of the law. Contemporary theories of interpretation, as offered by neopragmatism and various forms of poststructuralism, are gaining interest. There is a shift toward poststructuralist thinking about the theory of interpretation and about law itself, a change in the paradigm of judicial decision. Zirk-Sadowski explains this in the following manner: '...one cannot be deluded that we will be able to develop any direct linguistic meanings of legal texts. Moreover, language itself is active visà-vis reality. It is not the case that the linguistic expressions are simply 'applied' to reality. It is rather the manner in which we use them that affects our perception of reality. By means of learning one's mother tongue we learn to perceive reality differently than people of other cultures. If the latter is the case, the so-called 'clear' meaning of the text in a linguistic sense, is neither clear nor obvious' [17, pp. 475-476]. The derivational concept of interpretation is one of the factors leading to gradual acceptance of the thesis that the meaning of a legal text is not discovered by its interpreter based on the source of meaning given by the law maker-as the 'existence of direct meaning of the text' - but rather, it is created in the process of interpretation, under the influence of contextual and situational factors. Such a view, diverging from the traditional, formalistic approach, is represented by the philosophical pragmatist Stanley Fish, who rejects the thesis of 'one direct/plain meaning of the text'. In any interpretation, situational factors may be decisive, determining the validity of choosing not the literal or standard meaning, as Fish would say-'literal language', 'the ordinary', 'the obvious'-but the meaning justified by the requirements of the particular situation in which the text is interpreted [7, pp. 268, 284ff]. Fish analyzes the analogies between law and literature and stresses the role of the context and the interpreter in determining meaning. These factors are unavoidable in the process of interpretation, as they determine human cognition and existence. Proponents of contextualism, like Fish or Richard Rorty, ascribe a special role to literature. Literature is able to compete with other sciences, including philosophy, precisely because it is able to capture the situational nature of both language and human 
existence. These diagnoses apply not only to literary criticism, but to the whole of the humanities, including jurisprudence. Under the influence of cultural studies, the philosophy of legal interpretation is changing. Those who favor interpreting the law like a literary text oppose the imposition of predetermined principles and rules of interpretation. They deny the existence of a single correct model of interpretation, in which the interpreter has merely to determine the true (literary) meaning 'written into' a legal text. In this sense, research in law and literature is close to semiotics and hermeneutics. The cultural approach sets a challenge for a lawyer interpreting the law - the need to appreciate the tools of hermeneutic analysis and the ability to perform creative interpretation. In this context, it may be helpful to study works of literature and other cultural texts.

\section{Cultural Studies: What's New? What's Next?}

The central problem addressed here is the question of what the law and literature movement can derive from cultural studies. The answer to this question concerns changes of approach both in the philosophy of law and in legal practice, and has an impact on issues of interpretation, the notion of law and the approach to a text, as well as changes in the movement's methodology. Firstly, in the domain of the philosophy of law, that movement reflects the trends of abandoning formalism and textualism, and moving towards interpretationism. The concept of law as a social, cultural and political object, an area of human activity and creativity in the development of meanings, is opposed to the traditional positivist concepts of analytic theory and philosophy of law. This tendency is in line with the current directions of development of legal theory, such as politicality, post-analytic theory of law, the philosophy of dialogue, a reactivation of interest in the ethics of discourse. The poststructuralist approach to law, along with cultural studies, demonstrate the depletion of the methods and tools employed thus far. This shows us the nature of cultural thinking - the poststructuralist understanding of discourses refers to the cultural and institutional (and also legal) sphere, where knowledge and power are linked. This referral to cultural space, associated with social institutions that generate styles and discourses and create institutions of communication-'local' discourses-is based on conventional rules and assumptions. The pluralism of discourses involves a striving for coexistence and communication between diverse vocabularies (a concept developed by Rorty), traditions and conventions. The task of the humanities, including the law and literature movement, is to provide tools for that communication. Contemporary literary theory is being transformed under the influence of cultural studies. Texts are interpreted and analyzed in interdisciplinary research to decode social norms and attitudes. Although some researchers remain skeptical-for example Posner, who refers to such tendencies as the 'plague of interdisciplinarity' [13, pp. 6, 8]-they are becoming increasingly widespread and important. The culturally determined theory of literature-interdisciplinary in a specific way-is a research perspective that can be inspiring to those dealing with the law. The specifics of legal questions may be analyzed using the research tools of literary theory. In research on law and 
literature, certain subfields have developed, such as feminist legal theory and critical race theory. In turn, topics of interest to scholars of literature have come to include the theory of politics, gender studies, etc. In contemporary multicultural societies, these fields are linked by a common perspective.

Secondly, there is a change in the role of the law and lawyers-that is, in the sphere of legal practice. The cultural approach to law and literature presents 'new possibilities of balancing the one-sidedness of the technicalities of legal formalism and positivism by reintroducing literary and cultural activity in legal studies and education' [8]. The postmodern and poststructuralist movements demonstrate changes in the perception of the law in social reality. The role of the lawyer in legal culture is changing. This necessitates in turn a change in the paradigm of education. In formalistically oriented (especially Continental) jurisprudence, the traditionally applied 'formal-dogmatic method, linked with the code as an ideal regulation, excludes the lawyer's impact on cultural patterns associated with the law' [14, p. 480]. Ian Ward juxtaposes the universal nature and availability of literature with the hermetic nature of legal discourses. He stresses the importance of literature in a legal education. Thirdly, and perhaps most importantly, cultural determinants are changing the methodology of law and literature. Lawyers cannot do without language, but they treat it as a petrified, autonomous structure. Literature teaches us that language is 'a polyphonic construct that shows-importantly-the nuances of the human experience of existence' $[14$, p. 26]. He further stresses that by perceiving the law through the lens of literature, the fundamental legal questions such as responsibility and obligation can be brought to light. An example of such an approach is the work of David Gurnham, who analyzes the importance of memory and imagination preserved in the literature for the creation of images of the law and visions of justice [9, p. 4]. Ward regards the law represented in literature as a carrier of knowledge about humanity, a metaphor of the human condition [14, p. 22]. Richard A. Posner states that legal motifs in literature are present 'more often as a metaphor than as an object of interest in itself, even when the author is a lawyer or a law buff'. This is associated with 'the 'test of time' as the touchstone of literary distinction' [13, p. 21]. The legal metaphor supports the analysis of the human condition. As Ward notes, Kafka's The Trial does not tell us much about court procedure in Austria-Hungary [14, p. 12]. The state of accusation in which Joseph K. finds himself is rather a metaphor of the situation of contemporary man, entangled in the web of alienating interdependencies. Faced with these, the protagonist is unable to assume responsibility for his actions. They are not so much an image of actual problems or legal constructions, as their literary license. Kafka's trial does not reflect an actual legal matter or relate to a real court case; rather, it is a metaphor for existential, moral, social and similar problems. This metaphor can be read on various levels-in terms of legal and philosophical notions, or even references to Jewish mysticism, as pointed out by the author's biographers. Similarly, in Shakespeare's The Merchant of Venice we encounter equivocal visions of the law, different notions of its interpretation and application. The play contains elements representative of the law of sixteetth-century Venice, as well as constructs most probably derived from Roman jurisprudence. The legal motifs in the play enable numerous platforms of interpretation. They can be interpreted in the light of the author's biography, of the legal order of Venice, of 
the regulations and customs pertaining to the usury and commercial activities of the protagonists, of the antinomy of religious and ethical systems, and so on.

The perspective of cultural studies provides an opportunity for methodological expansion. As far as the law and literature movement itself is concerned, we may observe a broadening of this perspective: cultural studies enable the law to be examined not only through the classical distinction between law in literature and law as literature. Today we should not take literally the claim that literature can offer lawyers practical moral guidance on how to solve legal problems. Rather, it should be treated as an object of study, performed using the methods of literary analysis provided by literary theory and the theory of law. Lawyers should read works of literature not in a literal or direct way. This is necessary because, as Jeanne Gaakeer writes, language is not a neutral carrier of information, and what we consider to be reality and fact is influenced both by our conceptual framework and by the actual context. As language is a form of human behavior, the primary task of both law and literature is seen to be acceptance of the claim of the author or the speaker to determine the meaning. This brings us to the essence of hermeneutics and semiotics [8]. This is the heritage of cultural studies that can be used in the development of the law and literature movement. The analysis of literary works - as theoretician rather than reader-may give lawyers something that law studies cannot. Ian Ward shares a similar view_citing Rorty - if we want to understand the significant issues of the contemporary world, we must read the philosophy of Heidegger, along with the novels of Nabokov, Kafka or Orwell [14, p. 4]. And the education of lawyers should consider the need to 'indeed cherish the ambition of educating lawyers to be more than simply lawyers' [14, p. 27]. Rorty stresses the creative importance of fiction and metaphors in all types of texts which form material for a community striving to achieve the ideal 'human solidarity'. The interpretation and reception of a work in a scientific rather than a literal manner is a productive way in which literature can be used by law. We do not then need to make the conventional division between law in literature, law as literature, or other categories. The crux of the matter is that studies in the field of law and literature should be conducted not (only) from the standpoint of the reader's practice, but with the use of the tools of literary theory and philosophy of language, as employed in the philosophy of law. This means the discovery and solution of problems of the philosophy of law by or through literature.

Open Access This article is licensed under a Creative Commons Attribution 4.0 International License, which permits use, sharing, adaptation, distribution and reproduction in any medium or format, as long as you give appropriate credit to the original author(s) and the source, provide a link to the Creative Commons licence, and indicate if changes were made. The images or other third party material in this article are included in the article's Creative Commons licence, unless indicated otherwise in a credit line to the material. If material is not included in the article's Creative Commons licence and your intended use is not permitted by statutory regulation or exceeds the permitted use, you will need to obtain permission directly from the copyright holder. To view a copy of this licence, visit http://creativecommons.org/licen ses/by/4.0/. 


\section{References}

1. Andruszkiewicz, M. 2014. Interpretacja prawnicza a interpretacja literacka - kilka uwag. Krytyka Prawa 6: 183-197.

2. Andruszkiewicz, M. 2019. Prawo i literatura. O literackości w prawie. In Prawo i literatura. Parerga, ed. J. Kamień, J. Zajadło, and K. Zeidler. Gdańsk: Wydawnictwo Uniwersytetu Gdańskiego.

3. Andruszkiewicz, M., and K. Zeidler. 2016. Entry: Law and literature. In Wielka encyklopedia prawa. Tom VII Teoria i filozofia prawa, ed. A. Bator, J. Zajadło, and M. Zirk-Sadowski. Warsaw: Fundacja Ubi societas ibi ius.

4. Culler, J. 1997. Literary theory: A very short introduction. Oxford: Oxford University Press.

5. Culler, J. 2007. The literary in theory. Stanford, CA: Stanford University Press.

6. Dolin, K. 2007. A critical introduction to law and literature. Cambridge: Cambridge University Press.

7. Fish, S. ed. 1980. Normal circumstances, literal language, direct speech acts, the ordinary, the everyday, the obvious, what goes without saying, and other special cases. In Is there a text in this class? The authority of interpretive communities. Cambridge, MA: Harvard University Press.

8. Gaakeer, J. 2016. Law and literature. In IVR encyclopedia of jurisprudence, legal theory and philosophy of law. http://ivr-enc.info. Accessed 3 February 2016.

9. Gurnham, D. 2009. Memory, imagination, justice: Intersections of law and literature. Farnham: Ashgate Publishing Ltd.

10. Kozak, A. 2010. Myślenie analityczne $w$ nauce prawa i praktyce prawniczej. Wrocław: Wydawnictwo Uniwersytetu Wrocławskiego.

11. Minda, G. 1995. Postmodern legal movements. Law and jurisprudence at century's end. New York: New York University Press.

12. Minda, G. 1997. Law and literature and century's end. Cardoso Studies in Law and Literture 9(2): 245-258.

13. Posner, R.A. 2009. Law \& Literaure. 3rd ed. Cambridge, MA: Harvard University Press.

14. Ward, I. 1995. Law and literature. Possibilities and perspectives. Cambridge: Cambridge University Press.

15. White, J.B. 1990. Justice as translation. An essay in cultural and legal criticism. Chicago: University of Chicago Press.

16. Zirk-Sadowski, M. 1998. Prawo a uczestniczenie $w$ kulturze. Łódź: Wydawnictwo Uniwersytetu Łódzkiego.

17. Zirk-Sadowski, M. 2012. Interpretation of law and judges communities. International Journal for the Semiotics of Law 25(4): 473-487.

Publisher's Note Springer Nature remains neutral with regard to jurisdictional claims in published maps and institutional affiliations. 